REFERENCES

Benzing, G., III, Schubert, W., Hug, G., and Kaplan, S. (1969). Simultaneous hypoglycemia and acute congestive heart failure. Circulation, 40, 209.

Burnard, E. D., and James, L. S. (1961a). The cardiac silhouette in newborn infants: a cinematographic study of the normal range. Pediatrics, 27, 713.

- , and $-(1961 \mathrm{~b})$. Failure of the heart after undue asphyxia at birth. Pediatrics, 28, 545.

Dawes, G. S., Mott, J. C, and Shelley, H. J. (1959). The importance of cardiac glycogen for the maintenance. of life in foetal lambs and new-born animals during anoxia. Fournal of Physiology, 146, 516.

Gatti, R. A., Muster, A. J., Cole, R. B., and Paul, M. H. (1966). Neonatal polycythemia with transient cyanosis and cardiorespiratory abnormalities. Fournal of Pediatrics, 69, 1063.

Miller, H. C. (1944). Cardiac hypertrophy in newborn infants. Yale Fournal of Biology and Medicine, 16, 509.

Reilly, B. J., Reid, M. McC., Murdock, A. I., and Swyer, P. R. (1969) Heart failure in association with neonatal hypoglycemia. Presented at the 46th Annual General Meeting of the Canadian Paediatric Society, Montreal, 1969.

Shelley, H. J. (1964). Carbohydrate reserves in the newborn infant. British Medical fournal, 1, 273.

Wittels, B., and Bressler, R. (1965). Lipid metabolism in the newborn heart. Fournal of Clinical Investigation, 44, 1639.

O. Amatayakul, G. R. Cumming, and J. C. HAWORTH*

The Research Foundation, The Children's Hospital of Winnipeg: and the Department of Paediatrics, University of Manitoba, Canada.

^Address: The Children's Hospital, Winnipeg 3, Manitoba, Canada.

\section{Fasting Growth Hormone in Treated Diabetic Children}

Since growth hormone administration in diabetic patients causes deterioration of their diabetic state (Luft, 1965), the poor control seen in some diabetic children might be the result of increased growth hormone secretion. Diabetic control and growth hormone levels have been correlated in a series of diabetic children.

\section{Patients and Methods}

Twenty-four diabetic children who were treated with insulin for 1 to 10 years were investigated. 10 were girls and 14 were boys. Their ages ranged from 5 years to 15 years 9 months. In half, the diabetic control was considered good, while in the remaining half the control was poor. The criteria for assessment of diabetic control are shown in Table I.

Control data were obtained from 13 non-obese metabolically and endocrinologically normal children with no family history of diabetes or coronary disease. 6 were girls and 7 were boys. Their ages were similar to the diabetic children ranging from 4 years 8 months to 15 years 2 months.
TABLE I

Criteria used for Assessment of Diabetic Control

\begin{tabular}{|c|c|c|c|}
\hline & \multicolumn{2}{|c|}{$\begin{array}{l}\text { Preprandial Urine Specimens for } \\
\text { Glycosuria }\end{array}$} & \multirow{3}{*}{$\begin{array}{l}\text { Fasting Blood } \\
\text { Sugar } \\
\text { (mg./100 ml.) }\end{array}$} \\
\hline & \multicolumn{2}{|c|}{ Daily Second-Voided } & \\
\hline & a.m. & p.m. & \\
\hline $\begin{array}{l}\text { Good } \\
\text { control }\end{array}$ & $\begin{array}{c}\text { Mainly } 0 \% \text {; } \\
\text { occasionally } \\
0.5 \% \text {; no } \\
\text { ketonuria }\end{array}$ & $\begin{array}{l}\text { Mainly } 0 \% \text {; } \\
\text { occasionally } \\
\text { to } 1 \% \text {; no } \\
\text { ketonuria }\end{array}$ & $<120$ \\
\hline $\begin{array}{l}\text { Poor } \\
\text { control }\end{array}$ & $\begin{array}{l}\text { Frequent } \\
1-2 \% \text {; only } \\
\text { occasionally } \\
\text { sugar free; } \\
\text { any } \\
\text { ketonuria }\end{array}$ & $\begin{array}{l}\text { Frequent } \\
1-2 \% \text {; only } \\
\text { occasionally } \\
\text { sugar free; } \\
\text { any } \\
\text { ketonuria }\end{array}$ & $>160$ \\
\hline
\end{tabular}

All patients were fasted overnight. None of the diabetic children had received insulin before blood $\bigcirc$ collection. All diabetic children were treated with a mixture of semi-lente and ultra-lente insulin. Venous $O$ blood was collected from peripheral veins with minimal stasis. Aliquots were transferred to fluoride-oxalate tubes for glucose analysis and to heparin tubes for growth hormone assays. Plasma was stored at $-20^{\circ} \mathrm{C}$. until assayed. Blood glucose was determined by an automated glucose-oxidase method described by Discombe (1963); plasma growth hormone was measured by the double antibody radioimmunoassay method of Hartog et al. (1964).

\section{Results}

The fasting blood glucose and plasma growth hormone results from the control children and from the diabetic children are shown in Tables II and III.

\section{TABLE II}

Fasting Blood Glucose and Plasma Growth Hormone Levels in Control Children

\begin{tabular}{|c|c|c|c|c|}
\hline $\begin{array}{l}\text { Control } \\
\text { No. }\end{array}$ & Age (yr.) & Sex & $\begin{array}{c}\text { Fasting Blood } \\
\text { Glucose } \\
\text { (mg./100 ml.) }\end{array}$ & $\begin{array}{c}\text { Fasting HGH } \\
\text { (ng./ml.) }\end{array}$ \\
\hline $\begin{array}{r}1 \\
2 \\
3 \\
4 \\
5 \\
6 \\
7 \\
8 \\
9 \\
10 \\
11 \\
12 \\
13\end{array}$ & $\begin{array}{cl}4 & 8 / 12 \\
5 & \\
5 & 4 / 12 \\
5 & 6 / 12 \\
7 & 3 / 12 \\
7 & 11 / 12 \\
8 & 4 / 12 \\
9 & 1 / 12 \\
9 & 5 / 12 \\
13 & \\
13 & 6 / 12 \\
14 & 7 / 12 \\
15 & 2 / 12\end{array}$ & $\begin{array}{l}M \\
M \\
M \\
F \\
F \\
F \\
M \\
M \\
F \\
M \\
M \\
F \\
M\end{array}$ & $\begin{array}{l}64 \\
64 \\
66 \\
62 \\
64 \\
66 \\
63 \\
68 \\
58 \\
59 \\
79 \\
69 \\
72\end{array}$ & $\begin{array}{r}<1 \\
17 \\
<1 \\
2 \\
5 \\
<1 \\
<1 \\
<1 \\
<1 \\
<1 \\
2 \\
6 \\
1\end{array}$ \\
\hline $\begin{array}{l}\text { Mean } \\
\text { Range }\end{array}$ & $\begin{array}{r}78 / 12 \\
152 / 12\end{array}$ & & $\begin{array}{c}65 \cdot 6 \\
58-79\end{array}$ & $\begin{array}{c}3 \cdot 0 \\
<1-17\end{array}$ \\
\hline
\end{tabular}


TABLE III

Fasting Blood Glucose and Plasma Growth Hormone Levels in Treated Diabetic Children

\begin{tabular}{|c|c|c|c|c|}
\hline Case No. & Age (yr.) & Sex & $\begin{array}{l}\text { Fasting Blood } \\
\text { Glucose } \\
\text { (mg./100 ml.) }\end{array}$ & $\begin{array}{l}\text { Fasting HGH } \\
\text { (ng./ml.) }\end{array}$ \\
\hline \multicolumn{5}{|c|}{ Children with good control } \\
\hline $\begin{array}{c}1 \\
2 \\
3 \\
4 \\
5 \\
6 \\
7 \\
8 \\
9 \\
10 \\
11 \\
12 \\
\text { Mean } \\
\text { Range }\end{array}$ & $\begin{array}{cl}5 & \\
5 & 8 / 12 \\
7 & 9 / 12 \\
8 & \\
8 & 7 / 12 \\
9 & 7 / 12 \\
10 & 11 / 12 \\
11 & \\
11 & 4 / 12 \\
11 & 7 / 12 \\
12 & 7 / 12 \\
15 & 9 / 12\end{array}$ & $\begin{array}{l}F \\
M \\
F \\
M \\
F \\
F \\
M \\
M \\
M \\
M \\
F \\
M\end{array}$ & $\begin{array}{c}51 \\
65 \\
62 \\
104 \\
108 \\
89 \\
55 \\
110 \\
77 \\
45 \\
81 \\
58 \\
75 \cdot 4 \\
45-110\end{array}$ & $\begin{array}{r}10 \\
2 \\
5 \\
<1 \\
<1 \\
<1 \\
<1 \\
<1 \\
<1 \\
<1 \\
1 \\
1 \\
2 \cdot 1 \\
<1-10\end{array}$ \\
\hline \multicolumn{5}{|c|}{ Children with poor control } \\
\hline $\begin{array}{l}13 \\
14 \\
15 \\
16 \\
17 \\
18 \\
19 \\
20 \\
21 \\
22 \\
23 \\
24\end{array}$ & $\begin{array}{rr}6 & 4 / 12 \\
7 & 4 / 12 \\
7 & 9 / 12 \\
8 & 3 / 12 \\
9 & 9 / 12 \\
10 & 8 / 12 \\
11 & 3 / 12 \\
11 & 6 / 12 \\
12 & \\
12 & 6 / 12 \\
13 & 1 / 12 \\
14 & 8 / 12\end{array}$ & $\begin{array}{l}\text { M } \\
\mathbf{M} \\
\mathbf{F} \\
\mathbf{M} \\
\mathbf{F} \\
\mathbf{F} \\
\mathbf{M} \\
\mathbf{F} \\
\mathbf{M} \\
\mathbf{M} \\
\mathbf{F} \\
\mathbf{M}\end{array}$ & $\begin{array}{l}195 \\
219 \\
280 \\
228 \\
172 \\
245 \\
232 \\
234 \\
306 \\
264 \\
248 \\
198\end{array}$ & $\begin{array}{r}1 \\
13 \\
<1 \\
<1 \\
7 \\
<1 \\
<1 \\
<1 \\
3 \\
<1 \\
<1 \\
1\end{array}$ \\
\hline $\begin{array}{l}\text { Mean } \\
\text { Range }\end{array}$ & & & $\begin{array}{l}235 \\
172-306\end{array}$ & $\begin{array}{l}2 \cdot 6 \\
<1-13\end{array}$ \\
\hline
\end{tabular}

In the control group fasting blood glucose values ranged from 58 to $79 \mathrm{mg}$. $/ 100 \mathrm{ml}$. (mean $65 \cdot 6$ ) and growth hormone values ranged from less than 1 to $17 \mathrm{ng} . / \mathrm{ml}$. (mean 3.0).

In the diabetic children with good control fasting blood glucose values ranged from 45 to $110 \mathrm{mg}$./ $100 \mathrm{ml}$. (mean 75.4), and growth hormone values ranged from less than 1 to $10 \mathrm{ng}$. $/ \mathrm{ml}$. (mean $2 \cdot 1$ ).

In the diabetic children with poor control fasting blood glucose values ranged from 172 to 306 $\mathrm{mg}$./100 ml. (mean 235), and the growth hormone values ranged from less than 1 to $13 \mathrm{ng} . / \mathrm{ml}$. (mean 2.6).

\section{Discussion}

The rôle of growth hormone in the pathogenesis of diabetes mellitus has been argued since Young (1937) first showed the diabetogenic effect of anterior pituitary extracts. Normal fasting growth hormone levels have been previously reported by Drash et al. (1968), Parker et al. (1968), and Theodoridis et al. (1970), and raised levels have been noted by Johansen and Hansen (1969). The results presented here suggest that plasma growth hormone concentrations in treated patients with juvenile diabetes are not increased and do not approach the values associated with the development of diabetes in acromegaly. There was no difference in the growth hormone values obtained from the diabetic children whose control was good and from those whose control was poor, so that the poor diabetic control seen in some children is probably not related to an increased growth hormone production.

\section{Summary}

Fasting blood glucose and plasma growth hormone were measured in 24 treated diabetic children. Growth hormone was not raised and there was no relation between degree of diabetic control and plasma growth hormone levels.

We are indebted to Professor C. $M$. Anderson for her support and to the Consultant Staff of the Birmingham Children's Hospital for permission to investigate their patients.

\section{REFERENCES}

Discombe, G. (1963). An inexpensive method for estimation of true glucose in blood and other fluids by the Autoanalyzer. Fournal of Clinical Pathology, 16, 170.

Drash, A., Field, J. B., Garces, L. Y., Kenny, F. M., Mintz, D., and Vazquez, A. M. (1968). Endogenous insulin and growth hormone responses in children with newly diagnosed diabetes mellitus. Pediatric Research, 2, 94.

Hartog, M., Gaafar, M. A., Meisser, B., and Fraser, R. (1964). Immunoassay of serum growth hormone in acromegalic patients. British Medical fournal, 2, 1229.

Johansen, K., and Hansen, A. P. (1969). High 24-hour level of serum growth hormone in juvenile diabetics. British Medical Fournal, 2, 356.

Luft, R. (1965). Indication that human growth hormone plays a rôle in diabetes mellitus and diabetic retinopathy. In On the Nature and Treatment of Diabetes: Proceedings of the 5th Congress of the International Diabetes Federation, Excerpta Medica International Congress Series, 84. p. 496. Ed. by B. S. Leibel, and G. A. Wrenshall.

Parker, M. L., Pildes, R. S., Chao, K. L., Cornblath, M., and Kipnis, D. M. (1968). Juvenile diabetes mellitus, a deficiency in insulin. Diabetes, 17, 27.

Theodoridis, C. G., Chance, G. W., Brown, G. A., and Williams, J. W. (1970). Plasma insulin and growth hormone levels in untreated diabetic children. Archives of Disease in Childhood, 45, 70 .

Young, F. G. (1937). Permanent experimental diabetes produced by pituitary (anterior lobe) injections. Lancet, $2,372$.

C. G. Theodoridis, G. W. Chance, ${ }^{\star}$ and

B. T. RUDD

From the Institute of Child Health, Francis Road, Birmingham 16.

^Present address: Toronto Children's Hospital. 